\title{
SERUM LEVELS OF ASYMMETRIC AND SYMMETRIC DIMETHYLARGININE IN WOMEN WITH VITAMIN D DEFICIENCY AND HISTORY OF PREGNANCY LOSS - A PILOT STUDY
}

\author{
SERUMSKI NIVOI ASIMETRIČNOG I SIMETRIČNOG DIMETILARGININA KOD ŽENA \\ SA NEDOSTATKOM VITAMINA D I ISTORIJOM POBAČAJA - PILOT STUDIJA
}

\author{
Samar Damiati \\ Department of Biochemistry, Faculty of Science, King Abdulaziz University (KAU), Jeddah, Saudi Arabia
}

\begin{abstract}
Summary
Background: Vitamin D deficiency has been reported to be associated with pregnancy loss. Asymmetric dimethyl-L-arginine (ADMA) and symmetric dimethyl-L-arginine (SDMA) are arginine analogues that have direct and indirect effects on nitric oxide (NO) synthesis and endothelial dysfunction. This study aimed to evaluate ADMA and SDMA levels among women with history of pregnancy loss compared to women without history of pregnancy loss and all participants were suffering from vitamin $D$ deficiency.

Methods: To investigate the relationship between vitamin D deficiency and ADMA and SDMA, both groups of women were experiencing vitamin $D$ deficiency. All women enrolled in this study had a vitamin $D$ level below $75 \mathrm{nmol} / \mathrm{L}$ and were not pregnant. ADMA and SDMA levels were investigated in 28 women without a history of pregnancy loss and 19 women with a history of pregnancy loss.

Results: No statistically significant differences were found in ADMA and SDMA levels among the two groups. The correlation analysis showed that vitamin $D$ deficiency was not significantly inversely correlated with ADMA and SDMA in women without a history of pregnancy loss, but was significantly correlated with SDMA in women with a history of pregnancy loss.

Conclusions: Vitamin D deficiency, in women with or without a history of failed clinical pregnancies, has no effect on the circulating levels of ADMA and SDMA. Further studies are needed to investigate any possible link between these parameters.
\end{abstract}

Keywords: ADMA, SDMA, vitamin D deficiency, pregnancy loss

\section{Kratak sadržaj}

Uvod: Nedostatak vitamina $D$ doveden je u vezu s pobačajima. Asimetrični dimetil-L-arginin (ADMA) i simetrični dimetil-L-arginin (SDMA) analozi su arginina koji direktno i indirektno utiču na sintezu azot-oksida (NO) i endotelnu disfunkciju. Cilj ove studije bio je da se odrede nivoi ADMA i SDMA kod žena sa istorijom pobačaja u poređenju sa ženama bez istorije pobačaja a sve učesnice su patile od nedostatka vitamina D.

Metode: Da bi se ispitao odnos između nedostatka vitamina D i ADMA i SDMA, obe grupe žena patile su od nedostatka vitamina $D$. Sve žene uključene u ovu studije imale su nivoe vitamina $D$ ispod $75 \mathrm{nmol} / \mathrm{L}$ i nisu bile trudne. Nivoi ADMA i SDMA određeni su kod 28 žena bez istorije pobačaja i 19 žena sa istorijom pobačaja.

Rezultati: Nisu nađene statistički značajne razlike u nivoima ADMA i SDMA između dve grupe. Korelaciona analiza pokazala je da nedostatak vitamina $D$ nije bio u značajnoj obrnutoj korelaciji sa ADMA i SDMA kod žena bez istorije pobačaja, ali jeste bio u značajnoj korelaciji sa SDMA kod žena sa istorijom pobačaja.

Zaključak: Nedostatak vitamina $D$ kod žena sa i bez istorije neuspešnih kliničkih trudnoća nema uticaja na cirkulišuće nivoe ADMA i SDMA. Potrebne su dalje studije kako bi se istražile potencijalne veze između ovih parametara.

Ključne reči: $A D M A, S D M A$, nedostatak vitamina $D$, pobačaj

Address for correspondence:

Samar Damiati

Department of Biochemistry, Faculty of Science

King Abdulaziz University (KAU), Jeddah, SA

e-mail: sdamiati@kau.edu.sa 


\section{Introduction}

Pregnancy loss, also known as miscarriage, is an outcome of pregnancy that results in a dead-born child. The majority of miscarriages occur before the 12th week of gestation. Many pregnancies fail before being clinically recognized, whereas approximately $10-15 \%$ of clinically recognized pregnancies terminate with spontaneous loss $(1,2)$. Recurrent spontaneous abortion (RSA) is a negative pregnancy outcome, defined as two or more consecutive clinical pregnancies that terminate before 20 weeks of gestation $(3,4)$. However, causes of spontaneous pregnancy loss are unknown, but are thought to be related to hormonal problems, chromosomal abnormalities, uterine abnormalities, infections, and autoimmune disorders.

Vitamin D deficiency in pregnant women may be a factor that increases the risk of obstetrical complications, resulting in RSA or first trimester pregnancy loss. However, the effect of vitamin D on pregnancy is still unclear (5-7). Vitamin D is a lipid-soluble secosteroid hormone that plays a significant role in mineral homeostasis and bone metabolism $(8,9)$. Vitamin $D$ converts to its active form, 1,25-dihydroxy vitamin $D_{3}$, through 1- $\alpha$-hydroxylase and 25 -hydroxylase. Vitamin $D$ functions by combining with the nuclear vitamin $D_{3}$ receptor (VDR). Vitamin $D$ regulates cell proliferation and differentiation, modulates the immune response, and may control human reproductive processes $(10,11)$. Conversely, vitamin D deficiency contributes to several chronic diseases and is associated with infertility, preeclampsia, bacterial vaginosis, polycystic ovary syndrome, gestational diabetes, obstetrical outcome, and male gonadal function (12-16).

Vitamin D deficiency is a non-traditional cardiovascular risk factor that can be treated with oral supplementation. Cardiovascular risk factors, such as high blood pressure and abnormal blood lipid levels, can increase the risk of endothelial dysfunction. Decreased nitric oxide (NO) levels impair endothelium-dependent vasodilation, and result in endothelial dysfunction (17-19). Asymmetric dimethyl-L-arginine (ADMA) is an endogenous inhibitor of NO synthase (NOS) and considered an independent risk factor for cardiovascular diseases. ADMA inhibits NO synthesis by inhibiting NOS activity, leading to endothelial dysfunction $(20,21)$. Circulating ADMA levels fluctuate in several diseases, including diabetes, obesity, hypertension, hyperlipidemia, myocardial infraction, fertility, Alzheimer's dementia, and depression (21-31). The ADMA isomer, symmetric dimethyl-L-arginine (SDMA), does not directly affect NOS activity but may interfere with NO synthesis and endothelial dysfunction by competing with L-arginine transportation. However, SDMA is considered a sensitive marker for renal function. ADMA is eliminated through urinary excretion and is metabolized by dimethylarginine dimethylamino-hydrolase (DDAH), whereas SDMA is only renally excreted (32-34).

Since vitamin $D$ deficiency is associated with endothelial dysfunction markers, this study aimed to investigate ADMA and SDMA levels in women that suffer from vitamin $D$ deficiency and had experienced a miscarriage at least once in their lives.

\section{Materials and Methods}

\section{Participants}

Women aged between 20 and 54 years, with vitamin $D$ levels below $75 \mathrm{nmol} / \mathrm{L}$, and with or without a history of pregnancy loss were invited to participate in this study. Blood samples were collected from non-pregnant women after fasting. Serum samples were centrifuged at $3000 \mathrm{rpm}$ for $10 \mathrm{~min}$ to separate cells and the serum was stored at $-20{ }^{\circ} \mathrm{C}$ until further analysis.

All participants were informed about the study during their visit to King Abdullaziz University Hospital and each participant signed a written informed consent. Blood samples were collected with approval of the Ethics Board of King Abdulaziz University (Reference number 93-15).

\section{Biochemical analyses}

ADMA and SDMA levels were measured using competitive ELISA (DLD Diagnostika, Germany). Vitamin $D$ concentrations were measured by immunochemiluminescent assay (Siemens, U.S.), whereas glucose and cholesterol concentrations were determined using automatic colorimetric methods.

\section{Statistical analysis}

Version 22 of the Statistical Package for the Social Sciences (PSS) was used to perform the statistical analyses. Data are expressed as mean \pm standard deviation (SD) and the Pearson correlation coefficient was used to assess the significant correlation between vitamin $D, A D M A$, and SDMA.

\section{Results}

The study population characteristics are shown in Table I. By study design, all participants were women with deficient or insufficient vitamin $D$ levels and identified as one of two groups: women with uncomplicated pregnancies, and women with a history of 1-4 pregnancy losses. None of the measured variables, including median age, body mass index (BMI), systolic and diastolic blood pressure (SBP and DBP), glucose, cholesterol, vitamin D, ADMA, or SDMA, were statistically significantly different between the 
women either with or without a history of pregnancy loss. Vitamin $D$ concentrations were deficient in both groups $(53.61 \pm 24.36$ and $53.57 \pm 20.64 \mathrm{nmol} / \mathrm{L}$ for women with and without a history of miscarriages, respectively). No significant differences were observed in ADMA levels between women with and without a history of pregnancy loss $(0.69 \pm 0.09$ and $0.64 \pm 0.09 \mu \mathrm{mol} / \mathrm{L}$, respectively). SDMA levels were statistically meaningless for women both with and without a history of miscarriage $(0.94 \pm 0.23$ and $0.86 \pm 0.16 \mu \mathrm{mol} / \mathrm{L}$, respectively) (Figure 1).

To find a link with spontaneous abortion, the correlation between vitamin $D$ concentration and methylarginine (ADMA and SDMA) was analyzed in women suffering from vitamin $D$ deficiency. Figure 2 shows the scatter plots of vitamin D and ADMA concentrations in women with and without a history of pregnancy loss and vitamin $D$ deficiencies. As expected, vitamin $D$ levels were negatively correlated with ADMA for both groups, but the obtained results were not significantly correlated. No difference was found in ADMA levels between women with or without a history of pregnancy loss.

Similar to ADMA, SDMA levels were negatively and insignificantly correlated to vitamin $D$ levels in women without a history of miscarriage. In contrast, SDMA levels were positively and significantly correlated with vitamin $D(p<0.05)$ in women with a history of pregnancy loss (Figure 3). Table I/ summarizes the Pearson correlation analysis performed in this study.

Table I Biochemical characteristics of study population. Results are presented as mean \pm SD.

\begin{tabular}{|c|c|c|}
\hline & $\begin{array}{c}\text { Women without Pregnancy Loss History } \\
(\mathrm{n}=28)\end{array}$ & Women with Pregnancy Loss History ( $=19)$ \\
\hline Age $($ Years $)$ & $35.93 \pm 11.91$ & $39.16 \pm 10.02$ \\
\hline BMI $\left(\mathrm{kg} / \mathrm{m}^{2}\right)$ & $26.12 \pm 6.37$ & $28.80 \pm 5.49$ \\
\hline SBP $(\mathrm{mmHg})$ & $120.09 \pm 23.89$ & $126.14 \pm 21.77$ \\
\hline DBP $(\mathrm{mmHg})$ & $73.62 \pm 17.22$ & $55.71 \pm 38.61$ \\
\hline Glucose $(\mathrm{mmol} / \mathrm{L})$ & $4.81 \pm 0.63$ & $4.19 \pm 0.28$ \\
\hline Cholesterol $(\mathrm{mmol} / \mathrm{L})$ & $4.66 \pm 1.02$ & $53.61 \pm 22.89$ \\
\hline Vitamin D $(\mathrm{nmol} / \mathrm{L})$ & $53.57 \pm 20.64$ & $0.689 \pm 0.09$ \\
\hline ADMA $(\mu \mathrm{mol} / \mathrm{L})$ & $0.643 \pm 0.09$ & $0.935 \pm 0.23$ \\
\hline SDMA $(\mu \mathrm{mol} / \mathrm{L})$ & $0.856 \pm 0.16$ & 5.40 \\
\hline
\end{tabular}

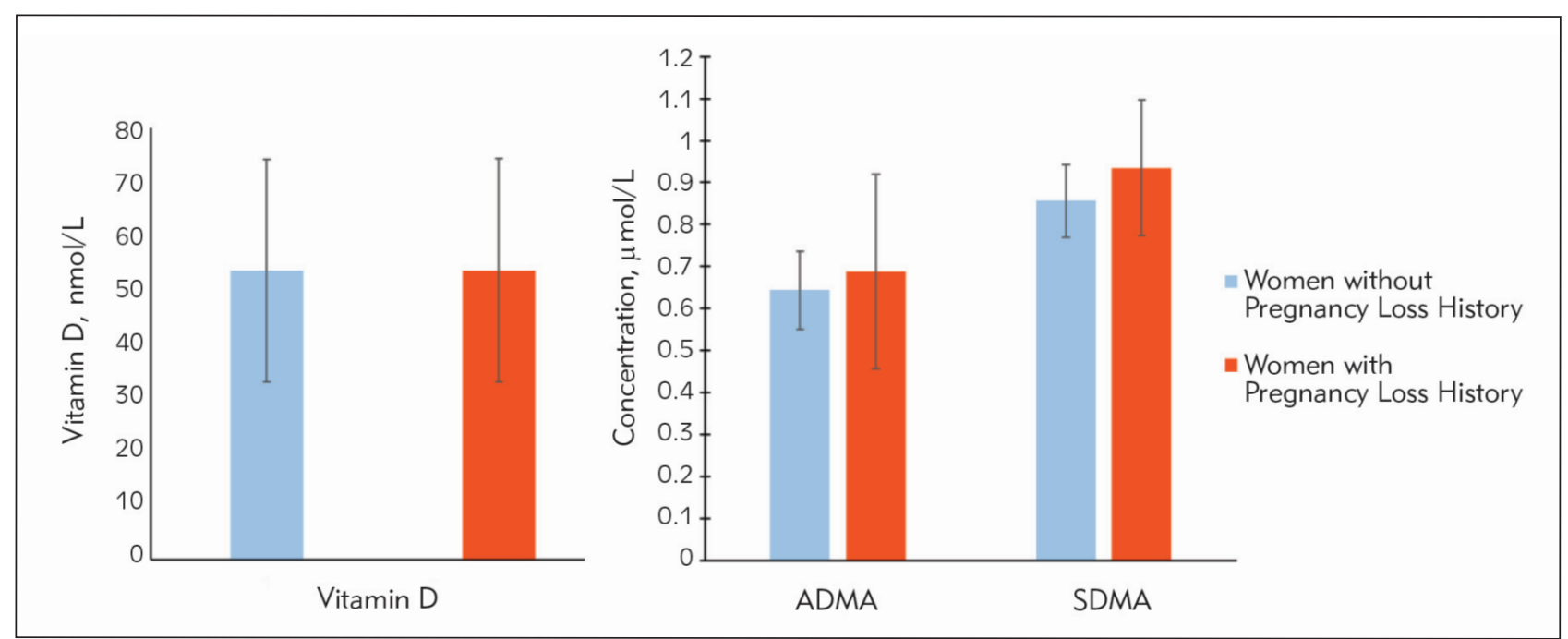

Figure 1 Concentrations of vitamin D, asymmetric dimethyl-L-arginine (ADMA), and symmetric dimethyl-L-arginine (SDAM) in women with and without a history of pregnancy loss. 


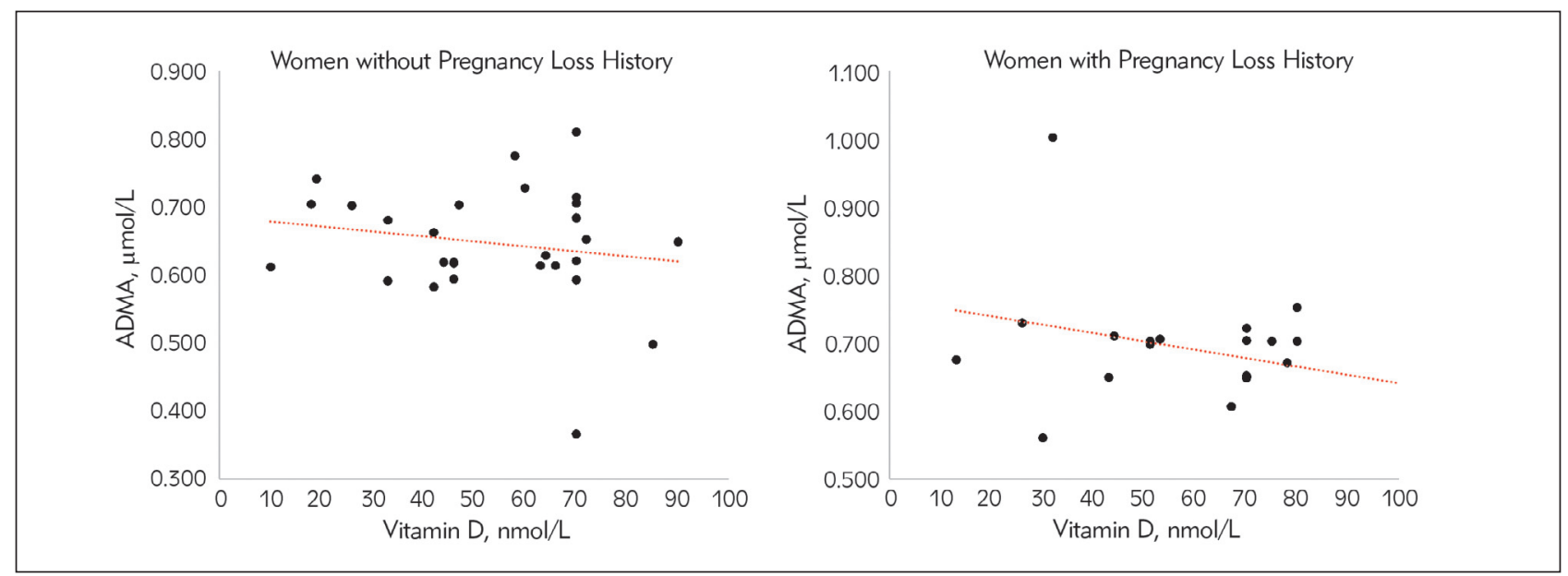

Figure 2 Correlation between vitamin D and ADMA concentrations in women with and without a history of pregnancy loss.

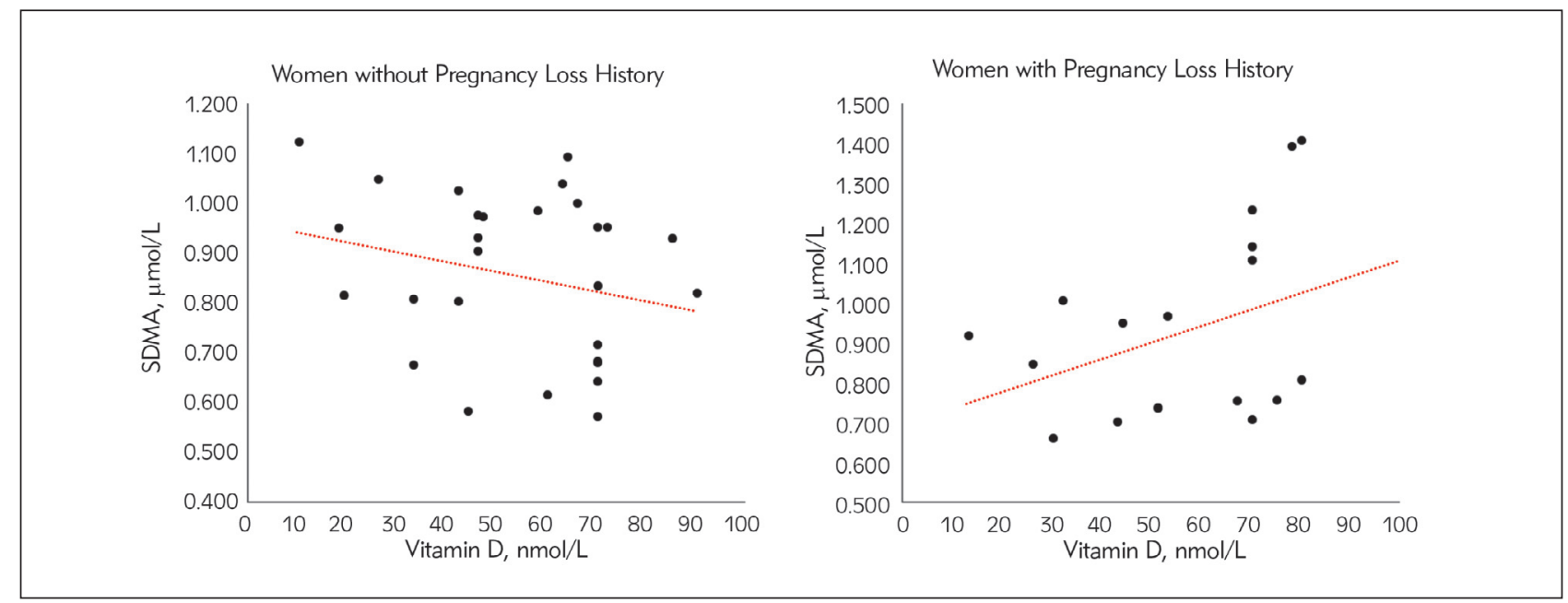

Figure 3 Correlation between vitamin D and SDMA concentrations in women with and without a history of pregnancy loss.

Table II Bivariate analysis of asymmetric dimethyl-L-arginine (ADMA) and symmetric dimethyl-L-arginine (SDMA) levels associated with vitamin $\mathrm{D}$ deficiency.

\begin{tabular}{|c|c|c|c|c|}
\hline & \multicolumn{2}{|c|}{$\begin{array}{c}\text { Women without } \\
\text { Pregnancy Loss History } \\
(\mathrm{n}=28)\end{array}$} & \multicolumn{2}{|c|}{$\begin{array}{c}\text { Women with } \\
\text { Pregnancy Loss History } \\
(\mathrm{n}=19)\end{array}$} \\
\hline & $\mathrm{p}$ & $\mathrm{r}$ & $\mathrm{p}$ & $\mathrm{r}$ \\
\hline ADMA & -0.176 & 0.185 & -0.301 & 0.105 \\
\hline SDMA & -0.250 & 0.199 & $0.407 *$ & 0.042 \\
\hline
\end{tabular}

* Correlation is significant at the 0.05 level.

\section{Discussion}

This study attempted to investigate the relationship of ADMA and SDMA concentrations with vitamin $D$ deficiency in women with and without a history of pregnancy loss. In the Pearson correlation analysis, ADMA and SDMA levels were statistically insignificant and negatively correlated with vitamin D deficiency in both groups. The exception were SDMA levels in women with a history of pregnancy loss, where the correlation with vitamin $D$ was significant and positive. Moreover, none of the measured variables showed a significant difference between the two groups of women.

Notably, a fluctuation in the measured methylarginine concentrations in the same disease has been reported in several studies. Several factors affect the circulating levels of arginine and its derivatives, including age, body mass index (BMI), diet, season, and gene polymorphism. In this paper, age and BMI were matched in both groups; therefore, ADMA and SDMA values were non-significant between groups. Dietary differences were not excluded as a possible factor affecting ADMA and SDMA concentrations. Samples were collected throughout the year, so the seasonal fluctuation may have impacted the obtained results. Previous studies reported that normal variation in diet does not influence circulating levels of arginine 
and methylarginines, even with complete exclusion of arginine from the diet or with oral supplementation of exogenous arginine $(34,35)$. In one study, a fluctuation in the ADMA levels was observed, and ADMA was found to be inversely associated with a seasonal fluctuation in vitamin D levels (36). The current study is mainly limited by collecting samples randomly throughout the year, and the small sample size, due to the restricted number of women suffering from vitamin $D$ deficiency and having a history of pregnancy loss.

The relationship between vitamin $D$ concentration and the incidence of heart disease has been investigated in several population studies $(17,19)$. Moreover, a direct association between vitamin D deficiency and endothelial dysfunction in mild to moderate chronic kidney disease patients was demonstrated by Chitalia et al. (17). Although several studies reported a significant correlation between vitamin $D$ deficiency and endothelial dysfunction, the mechanism has not yet been comprehensively studied (3537). Methylarginines (ADMA and SDMA) are important biomarkers for cardiovascular disease (21), progression of renal failure $(40,41)$, and death $(42$, 43). Hence, these two biomarkers may influence $\mathrm{NO}$ and cause endothelial dysfunction in several diseases.

A significant independent association between vitamin D deficiency and elevated levels of ADMA has been observed in previous studies $(17,36,43)$. Patients with chronic kidney disease that were treated with Paricalcitol, a vitamin D receptor agonist, showed short-term significant reduction in ADMA concentration (44). Since vitamin D levels are inversely correlated with ADMA, this phenomenon can be explained by the antioxidant activity of vitamin $D$ that is associated with a decrease in lipid peroxidation and an improvement in endothelial function (43). Thus, antioxidant activity improves DDAH activity and reduces type 1 protein arginine methyltransferase (PRMT) activity, subsequently enhancing ADMA degradation which reduces its production $(44,45)$. In comparison, a meta-analysis of 51 studies found a non-significant effect between vitamin $D$ and cardiovascular diseases (46). Moreover, previous studies found that vitamin D levels were not significantly associated with ADMA and SDMA levels. Maaty et al. (47) reported on a non-significant association between ADMA, SDMA, and vitamin $D$. Although they found that vitamin $D$ participates in activating the NO system, vitamin D did not influence the endothelial function by modulating ADMA or SDMA levels (47). An insignificant reduction of ADMA and SDMA concentrations by oral vitamin $D$ supplementation in patients with arterial hypertension was observed in a study performed by Grübler et al. (48). These results may be attributed to different ethnicities and different frequencies of polymorphisms of vitamin $D$ genes, such as vitamin $D$ receptors (VDR), which may influence the ADMA and SDMA levels in different studies.
Changes in methylarginine concentrations were small in response to pregnancy; plasma concentrations of ADMA and SDMA declined in early pregnancy. In normal pregnancies, maternal ADMA levels were lower than in non-pregnant women. This finding suggested that ADMA may act as a key regulator for vasodilation and blood pressure in normal pregnancy (49). Saarelainen et al. (50) assumed that ADMA regulates blood pressure in pregnancy, and changes in maternal arginine or ADMA levels were not correlated to endothelium-dependent vasodilation. Rijvers et al. (51) suggested that ADMA and SDMA play a modest role in the pathogenesis of hypertensive pregnancy in women at high risk of recurrent hypertensive disorder. However, Hou et al. (52) demonstrated that vitamin D deficiency is associated with miscarriages. They reported that women with normal pregnancies have higher vitamin D concentrations than women with first trimester miscarriages. Hence, this study attempted to find a link between vitamin $D$ deficiency and methylarginines in women with a history of pregnancy loss. The obtained data showed slightly higher ADMA and SDMA levels in women with a history of pregnancy loss than women without a history of pregnancy loss, although this difference was not statistically significant, suggesting no appreciable effect of ADMA or SDMA function and metabolism on pregnancy loss. In one study, ADMA and SDMA concentrations were measured in women with preeclampsia (53). ADMA was slightly elevated in maternal circulation, whereas SDMA was significantly elevated in maternal and fetal circulatory systems, which may be attributed to a reduction of renal clearance. Hence, SDMA could be considered as a marker of mild renal dysfunction in preeclampsia. In another study, maternal ADMA and SDMA levels were not elevated in moderate preeclampsia, whereas ADMA was elevated in severe preeclampsia (54).

\section{Conclusions}

To the best of the author's knowledge, this is the first attempt to study the effect of a history of pregnancy loss on circulating ADMA and SDMA levels in women suffering from vitamin $D$ deficiency. Although the main findings of this study were negative, as the obtained results showed no significant correlation between ADMA or SDMA and vitamin D deficiency, the possible link between vitamin $D$ deficiency and endothelial dysfunction in women with a history of pregnancy loss requires further investigation.

\section{Conflict of interest statement}

The author stated that she has no conflicts of interest regarding the publication of this article. 


\section{References}

1. Macklon NS, Geraedts JPM, Fauser BCJM. Conception to ongoing pregnancy: the »black box« of early pregnancy loss. Hum Reprod Update 2002; 8: 333-43.

2. The Practice Committee of the American Society for Reproductive Medicine. Evaluation and treatment of recurrent pregnancy loss: a committee opinion. Fertil Steril 2012; 98: 1103-11.

3. Comba C, Bastu E, Dural O, Yasa C, Keskin G, Ozsurmeli $M$, et al. Role of inflammatory mediators in patients with recurrent pregnancy loss. Fertil Steril 2015; 104: 146774.

4. Lee SK, Kim JY, Lee M, Gilman-Sachs A, Kwak-Kim J. Th17 and regulatory $T$ cells in women with recurrent pregnancy loss. Am J Reprod Immunol 2012; 67: 31118.

5. Urrutia RP, Thorp JM. Vitamin D in pregnancy: current concepts. Curr Opin Obstet Gynecol 2012; 24: 57-64.

6. Ota K, Dambaeva S, Han AR, Beaman K, Gilman-Sachs A, Kwak-Kim J. Vitamin D deficiency may be a risk factor for recurrent pregnancy losses by increasing cellular immunity and autoimmunity. Hum Reprod 2014; 29: 208-19.

7. Andersen LB, Jørgensen JS, Jensen TK, Dalgård C, Barington T, Nielsen J, et al. Vitamin D insufficiency is associated with increased risk of first-trimester miscarriage in the Odense Child Cohort. Am J Clin Nutr 2015; 102: 633-8

8. Holick MF. Vitamin D deficiency. N Engl J Med 2007; 357: 266-81.

9. Tamblyn JA, Hewison M, Wagner CL, Bulmer JN, Kilby MD. Immunological role of vitamin $D$ at the maternalfetal interface. J Endocrinol 2015; 224: 107-21.

10. Lagishetty $\bigvee$, Liu NQ, Hewison M. Vitamin D metabolism and innate immunity. Mol Cell Endocrinol 2011; 347: 97-105.

11. Bikle DD. Vitamin $D$ regulation of immune function. Vitam Horm 2011; 86: 1-21.

12. Bodnar LM, Catov JM, Simhan HN, Holick MF, Powers RW, Roberts JM. Maternal vitamin D deficiency increases the risk of preeclampsia. J Clin Endocrinol Metab 2007; 92: 3517-22.

13. Cho GJ, Hong SC, Oh MJ, Kim HJ. Vitamin D deficiency in gestational diabetes mellitus and the role of the placenta. Am J Obstet Gynecol 2013; 209: e1-e8.

14. Bodnar LM, Krohn MA, Simhan HN. Maternal vitamin D deficiency is associated with bacterial vaginosis in the first trimester of pregnancy. J Nutr 2009; 139: 1157-61.

15. Franasiak JM. Vitamin D in human reproduction-an evolving landscape. Fertil Steril 2016; 106: 1650-1.

16. Karras S, Anagnostis P, Kotsa K, Goulis DG. Vitamin D and gonadal function in men: a potential inverse $U$ shaped association? Andrology 2016; 4: 542-4.

17. Chitalia N, Recio-Mayoral A, Kaski JC, Banerjee D. Vitamin $D$ deficiency and endothelial dysfunction in nondialysis chronic kidney disease patients. Atheroscler 2012; 220: 265-8.
18. Ambrus C, Almasi C, Berta K, Deak G, Marton A, Molnar MZ, Nemeth Z, Horvath C, Lakatos P, Szathmari M, Mucsi I. Vitamin $D$ insufficiency and bone fractures in patients on maintenance hemodialysis. Int Urol Nephrol 2011; 43: 475-82.

19. Gokce N, Keaney JF Jr, Hunter LM, Watkins MT, Nedeljkovic ZS, Menzoian JO, Vita JA. Predictive value of noninvasively determined endothelial dysfunction for longterm cardiovascular events in patients with peripheral vascular disease. J Am Coll Cardiol 2003; 41: 1769-75.

20. Boger RH. The pharmacodynamics of L-arginine. J Nutr 2007; 137(6): 1650S-1655S

21. Cooke JP. ADMA: its role in vascular disease. Vasc Med 2005; 10(Suppl 1): S11-7.

22. Eid HM, Eritsland J, Larsen J, Arnesen H, Seljeflot I. Increased levels of asymmetric dimethylarginine in populations at risk for atherosclerotic disease. Effects of pravastatin. Atherosclerosis 2003; 166: 279-84.

23. Furuki $K$, Adachi $H$, Enomoto $M$, Otsuka $M$, Fukami $A$, Kumagae S, Matsuoka H, Nanjo Y, Kakuma T, Imaizumi T. Plasma level of asymmetric dimethylarginine (ADMA) as a predictor of carotid intima-media thickness progression: six-year prospective study using carotid ultrasonography. Hypertension Research - Clinical \& Experimental 2008; 31: 1185-9.

24. Krzyzanowska K, Mittermayer F, Kopp HP, Wolzt M, Schernthaner G. Weight loss reduces circulating asymmetrical dimethylarginine concentrations in morbidly obese women. J Clin Endocrinol Metab 2004; 89: 627781.

25. Damiati S, Khoja S. Serum concentrations of asymmetric dimethyl-L-arginine in diabetes mellitus and hyperlipidemia. Clin Exp Med J 2009; 3: 443-52.

26. Damiati S, Khoja S. Serum asymmetric dimethyl-L-argnine in renal failure patients living in Jeddah region, Saudi Arabia. Trends in Medical Research 2011; 6: 1422.

27. Fadhel B, Zamzami M, Damiati S, Khoja S. Relationship between Serum Asymmetric Dimethyl L-arginine and Type 1 Diabetes Mellitus. Life Science Journal 2014; 11(12): 846-52.

28. Selley ML. Increased (E)-4-hydroxy-2-nonenal and asymmetric dimethylarginine concentrations and decreased nitric oxide concentrations in the plasma of patients with major depression. J Affect Disord 2004; 80: 249-56.

29. Speer PD, Powers RW, Frank MP, Harger G, Markovic N, Roberts JM. Elevated asymmetric dimethylarginine concentrations precede clinical preeclampsia, but not pregnancies with small-for-gestational-age infants. Amer J Obst Gyne 2008; 198: 112.e1-7.

30. Selley ML. Increased concentrations of homocysteine and asymmetric dimethylarginine and decreased concentrations of nitric oxide in the plasma of patients with Alzheimer's disease. Neurobiol Aging 2003; 24: 903-7.

31. Zsuga J, Torok J, Magyar MT, Valikovics A, Gesztelyi R, Lenkei A, Csiba L, Keki S, Zsuga M, Bereczki D. Dimethylarginines at the crossroad of insulin resistance and atherosclerosis. Metabolism 2007; 56: 394-9. 
32. Sibal L, Agarwal SC, Home PD, Boger RH. The role of asymmetric dimethylarginine (ADMA) in endothelial dysfunction and cardiovascular disease. Curr Cardiol Rev 2010; 6(2): 82-90.

33. Boger RH. Asymmetric dimethylarginine (ADMA): a novel risk marker in cardiovascular medicine and beyond. Ann Med 2006; 38: 126-36.

34. Rytlewski K, Olszanecki R, Korbut R, Zdebski Z. Effects of prolonged oral supplementation with I-arginine on blood pressure and nitric oxide synthesis in preeclampsia. Eur J Clin Invest 2005; 35: 32-7.

35. Raw A, Gallaher M, Powers RW. Arginine and ADMA in pregnant women with major depression. Psychosomatic Medicine 2014; 76(6): 430-6.

36. Ngo DT, Sverdlov AL, McNeil JJ, Horowitz JD. Does vitamin $D$ modulate asymmetric dimethylarginine and Creactive protein concentrations? Am J Med 2010; 123 (4): 335-41.

37. Tarighi S, Najafi M, Hossein-Nezhad A, Ghaedi H, Meshkani R, Moradi N, Fadaei R, Kazerouni F, Shanaki M. Association between two common polymorphisms of vitamin $D$ binding protein and the risk of coronary artery disease: A case-control study. J Med Biochem 2017; 36: 349-57.

38. Choi HR, Lee SW, Yeom H, Jeon D-H, Kim HC, Youm Y. Association between vitamin $\mathrm{D}$ status and asymmetric dimethylarginine (ADMA) concentration in the Korean elderly population. Maturitas 2017; 102: 13-17.

39. Fliser D, Kronenberg F, Kielstein JT, Morath C, BodeBöger SM, Haller $\mathrm{H}$, et al. Asymmetric dimethylarginine and progression of chronic kidney disease: the mild to moderate kidney disease study. J Am Soc Nephrol 2005; 16: 2456-61.

40. Ravani P, Tripepi G, Malberti F, Testa S, Mallamaci F, Zoccali C. Asymmetrical dimethylarginine predicts progression to dialysis and death in patients with chronic kidney disease: a competing risks modeling approach. J Am Soc Nephrol 2005; 16: 2449-55.

41. Zoccali C, Bode-Böger S, Mallamaci F, Benedetto F, Tripepi G, Malatino L, et al. Plasma concentration of asymmetrical dimethylarginine and mortality in patients with end-stage renal disease: a prospective study. Lancet 2001; 358: 2113-17.

42. Aucella F, Maas R, Vigilante M, Tripepi G, Schwedhelm $E$, Margaglione $M$, et al. Methylarginines and mortality in patients with end stage renal disease: a prospective cohort study. Atherosclerosis. Elsevier Ireland Ltd 2009; 207: 541-5.

43. Al-Azzawi AM, Ghoneim AH, Elmadbouh I. Evaluation of Vitamin D, Vitamin D Binding Protein Gene Polymorphism with oxidant - antioxidant Profiles in Chronic
Obstructive Pulmonary Disease. J Med Biochem 2017; 36: 331-40.

44. Pai AB. Changes in plasma levels of asymmetric dimethylarginine in chronic kidney disease patients treated for 8 weeks with the vitamin $D$ receptor agonist paricalcitol. J Res Dev 2015; 3: 129.

45. Schwedhelm E, Böger RH. The role of asymmetric and symmetric dimethylarginines in renal disease. Nature Rev Nephrol 2011; 7 (5): 275-85.

46. Elamin MB, Abu Elnour NO, Elamin KB. Vitamin D and cardiovascular outcomes: a systematic review and metaanalysis. J Clin Endocrinol Metab 2011; 96: 1931-42.

47. Maaty MA, Hassanein SI, Hanafi RS. Insights on vitamin D's role in cardiovascular disease: investigating the association of 25-hydroxyvitamin D with the dimethylated arginines. J Nutr Sci Vitaminol (Tokyo) 2013; 59(3): 172-7.

48. Grübler M, Gaksch M, Kienreich K, Müllner C, Trummer C, Schwetz V, Pilz S, Verheyen ND, Schmid J, Tomaschitz A, Richtig G, Scharnagl H, Meinitzer A, März W, Pieske B. Effects of Vitamin D3 on asymmetric and symmetric dimethylarginine in arterial hypertension. J Steroid Biochem Mol Biol 2018; 175: 157-63.

49. Maeda T, Yoshimura T, Okamura H. Asymmetric dimethylarginine, an endogenous inhibitor of nitric oxide synthase, in maternal and fetal circulation. J Soc Gynecol Investig 2003; 10: 2-4.

50. Saarelainen $H$, Valtonen $P$, Punnonen $K$, Laitinen $T$, Raitakari OT, Juonala M, Heiskanen N, Lyyra-Laitinen T, Viikari JS, Vanninen E, Heinonen S. Subtle changes in ADMA and L-arginine concentrations in normal pregnancies are unlikely to account for pregnancy-related increased flow-mediated dilatation. Clin Physiol Funct Imaging 2008; 28: 120-4.

51. Rijvers CA, Spaanderman ME, Peeters LL, Marzano S, Winkens B, Bakker JA, Kroon AA. Early-pregnancy asymmetric dimethylarginine (ADMA) levels in women prone to develop recurrent hypertension. Pregnancy Hypertension 2013; 3: 118-23.

52. Hou W, Yan XT, Bai CM, Zhang XW, Hui LY, Yu XW. Decreased serum vitamin $D$ levels in early spontaneous pregnancy loss. Eur J Clin Nutr 2016; 70(9): 1004-8.

53. Braekk K, Ueland P, Harsem N, Staff A. Asymmetric Dimethylarginine in the Maternal and Fetal Circulation in Preeclampsia. Pediatr Res 2009; 66: 411-5.

54. Maas R, Boger RH, Schwedhelm E, Casas JP, Lopez-Jaramillo $P$, Serrano N, Diaz LA. Plasma concentrations of asymmetric dimethylarginine (ADMA) in Colombian women with pre-eclampsia. JAMA 2004; 291: 823-4. 